\title{
Fibronectin によるプラーク・歯石の形成機序
}

第 8 報 Fibronectin による歯垢由来細菌の凝集及び

Hydroxyapatite への吸着に及ぼす影響

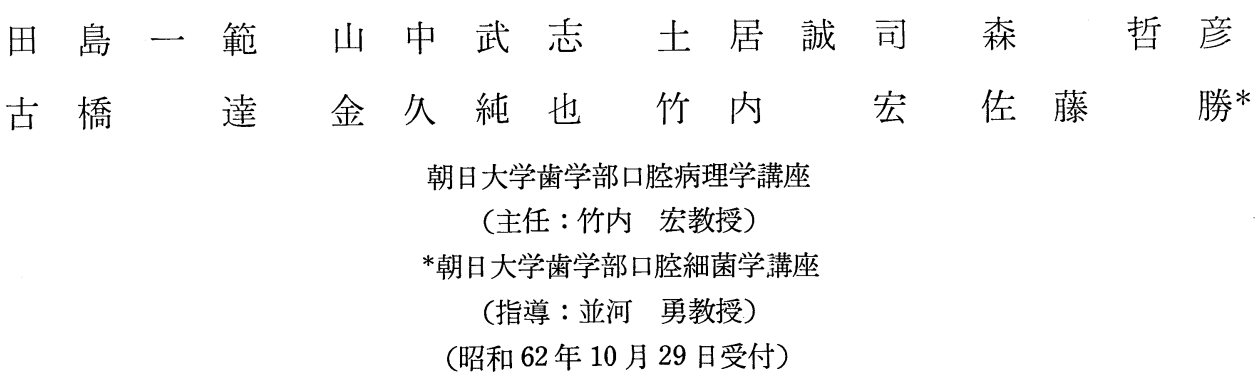

\section{The Mechanism of Dental Plaque and Dental Calculs Formation by Fibronectin}

8. Effect of Fibronectin on Bacterial Aggregation and Adsorption to Hydroxyapatite

\author{
Kazunori TAJIMA, Takeshi YAMANAKA, Seishi DOI, Tetsuhiko MORI, \\ Itaru FURUHASHI, Junya KANEHISA, Hiroshi TAKEUCHI and Masaru SATO* \\ Department of Oral Pathology \\ (Chief : Prof. Hiroshi TAKEUCHI) \\ *Department of Oral Microbiology \\ (Director : Prof. Isamu NAMIKAWA)
}

The effect of fibronectin (FN) on bacterial aggregation and adsorption to hydroxyapatite (HAp) was investigated to clarify the mechanisms whereby acquired pellicle and dental plaque were precipitated on the tooth surface. The FN prepared from human blood plasma amplified aggregation of bacteria which had been derived from dental plaque and cultured under aerobic and anaerobic states. The peaks of the aggregation were at the $\mathrm{FN}$ concentration of $3 \times 2^{3} \mu \mathrm{g} / \mathrm{m} l$ for the aerobic sample and at the $\mathrm{FN}$ concentration of $3 \times 2^{2} \mu \mathrm{g} / \mathrm{m} l$ for the anaerobic sample. The adsorption of the bacteria to synthesized HAp The adsorption of the bacteria to synthesized HAp was also amplified under the presence of FN. The peaks of the adsorption were at the FN concentration of $3 \times 2^{3} \mu \mathrm{g} / \mathrm{m} l$ for aerobic sample and at the FN concentration of $3 \times 2^{2} \mu \mathrm{g} / \mathrm{m} l$ for anaerobic sample. The present data suggest that $\mathrm{FN}$ may play a role in precipitation of acquired pellicle and dental plaque like many other salivary proteins do.

Key words : Fibronectin, Dental plque, Hydroxyapatite, Aggregation, Adsorption

要旨：ペリクルおよび歯垢形成におけるフィブロネクチン（FN）の役割を明らかにするために, FN の口腔内細菌 の凝集とハイドロキシアパタイト (HAp) への吸着に及ぼす影響について検索した。すなわち, 好気的又は嫌気的に 
培養した歯垢細菌をヒト血漿 FN 溶液中に䀣濁させ, 異なった菌濃度, FN 濃度での㠜集程度を, および同様の系に HAp 粉末を混ぜ, HAp への菌の吸着程度を調べた。その結果，菌濃度とは無関係に FNにより凝集が促進され，そ のピークは, 好気性サンプルでは $3 \times 2^{3} \mu \mathrm{g} / \mathrm{m} l$, 嫌気性サンプルでは $3 \times 2^{2} \mu \mathrm{g} / \mathrm{m} l$ の $\mathrm{FN}$ 濃度にあり, それ以下でも, 以上でも凝集は弱くなる傾向を示した。一方, HAp への菌の吸着も FN により促進され, 好気性サンプルを用いた 場合, ピークは $3 \times 2^{3} \mu \mathrm{g} / \mathrm{m} l \mathrm{FN}$ 濃度にあり，嫌気性サンプルでは $3 \times 2^{2} \mu \mathrm{g} / \mathrm{m} l \mathrm{FN}$ 濃度にあった。以上の結果から, $\mathrm{FN}$ は $\mathrm{Ca}^{++}$反応性, 細菌凝集性唾液タンパクと同様に, ペリクルおよび歯垢形成に直接関与じていることが強く示 唆された。

索引用語 : フィブロネクチン，歯垢，ハイドロキシアパタイト，凝集，吸着

\section{緒言}

歯垢は，唾液に由来する糖タンパクがエナメル質表面 に吸着してペリクルを形成し1)，それを基盤に口腔内細 菌が付着し，増殖して形成に至ると考えられている。歯 垢の主成分である口腔内細菌の歯表面への吸着, 付着の 様式は, 菌種あるいは菌体間相互作用, 刻々と変化する 各個の口腔内環境などをはじめ複雑な要因に関連してい るため, 極めて多様であると考えられるが，静電気的メ カニズム ${ }^{2 \sim 6)}$, 菌体表層タンパクとペリクル内糖残 基 間 の特異的結合 ${ }^{7,8)}$, 菌体間の凝集現象 ${ }^{9)}$ などが関連してい ることが明らかにされつつある。特に近年では，唾液由 来の一部の酸性糖タンパクが，細菌凝集因子として作用 すると共に，Hydroxyapatite（HAp）にも強い親和性 を有することが注目され，歯垢形成メカニズムの中軸と なる因子として諸学者の活発な議論の的となってい

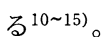

我々は, それらの唾液由来の酸性糖タンパクグループ に，生体組織にあまねく存在する Fibronectin ${ }^{16,17) （ 以 ~}$ 下 FN と略す）と共通した抗原性をもつ FN 類似タンパ ク，あるいは酵素で分解されたと考えられる FN フラグ メントが含まれている可能性があることを, 免疫組織学 的18 20), Elisa による定量 ${ }^{21)}$ などの実験結果に基づいて 報告してきた。血漿性あるいは細胞性 FN が具備する多 様な生物学的活性の中には, 細 菌, 細胞との結 合 作 用 ${ }^{22 ~ 28)}$, 細胞増殖促進作用 ${ }^{7,16)}, \mathrm{HAp}^{29,30)}$ との結合作用 など，唾液糖タンパクの性状に共通しているものが多 く, 唾液中に存在する $\mathrm{FN}$ 類似あるいは FN 由来のタン パクやペプチッドが単にペリクル形成のみならず，同時 に歯垢形成に直接関連していることが強く示唆される。

今回, 歯垢形成の FN の関連性を検討するために, FN 溶液中での歯垢由来細菌の凝集度, および $\mathrm{FN}$ 存在下で の細菌の HAp に対する吸着度を測定した結果を報告す る。

\section{実験試料及び方法}

\section{1. 血漿 Fibronectin（以下 FN と略す）の精製}

健常人から採血した血液を $4^{\circ} \mathrm{C} に て ~ 10,000 \times \mathrm{g} 20$ 分 間遠沈する事により血球成分を除去し，得られた血墏に $0.2 \mathrm{~N}$ EDTA 溶液を $25 \mathrm{~m} l / l$ 加えた。この EDTA 加血 漿を $37^{\circ} \mathrm{C}$ の恒温槽中で 30 分間加温, 攪汼した後, 予め 開始バッファー (10 mM Tris- $\mathrm{HCl}, 0.15 \mathrm{M} \mathrm{NaCl}, 5 \mathrm{mM}$ EDTA : pH 7.40) で洗っておいた gelatin-Sepharose 4 B (Pharmacia 社製) を充填したシリコン処理カラムに, $20 \mathrm{ml} / \mathrm{hr}$ の速度で流した。続いて, 開始バッファー,さ らに第 2 バッファー ( $10 \mathrm{mM}$ Tris- $\mathrm{HCl}, 1 \mathrm{M} \mathrm{NaCl}, 1$ $\left.\mathrm{mM} \mathrm{CaCl}_{2}: \mathrm{pH} 7.40\right)$ を流し，非結合性蛋白を洗い流し た。次に $1.5 \mathrm{ml} / \mathrm{hr}$ の速度で溶出バッファー $(10 \mathrm{mM}$ Tris-HCl, 4 M Urea : pH 7.40) を流して FN を溶出さ せ，FN の存在する分画を分光光度計 $(280 \mathrm{~nm})$ で確認 した後収集した。これによって得た溶液を $10 \mathrm{mM}$ Tris$\mathrm{HCl}(\mathrm{pH} 7.4)$ で 3 日間透析後，凍結乾燥標品として実 験に供した。

\section{2. 歯垢由来細菌浮遊液の調製}

健常人に 24 時間口腔清掃を中止させ，唇煩側及び 舌 口蓋側の歯肉縁上に形成された歯垢を採取後，速やかに Brain Heart Infusion (Difco 社製) 及び Gam Broth （Nissui 社製）に浮遊させた。前者は通法に従い $37^{\circ} \mathrm{C}$ 好気条件下で 48 時間培養した（以下好気性サンプル)。 後者は嫌気ジャーを用い, 96 時間嫌気培養を行った（以 下嫌気性サンプル)。これにより得た各々の細菌群を $4^{\circ} \mathrm{C}$ にて $10,000 \times \mathrm{g} 20$ 分間遠沈することにより回収した後, 0.01 MPBS（pH 7.00）にて同一条件で 3 回遠沈洗浄を 行った。これを $0.01 \mathrm{M}$ PBS 中にて懸濁し, 超音波破砕 器を用いて $9,000 \mathrm{~Hz}, 100 \mathrm{~W}, 5$ 分間超音波処理を行い, 異種及び同種菌体間凝集していた細菌を均一に浮遊させ 実験に供した。 


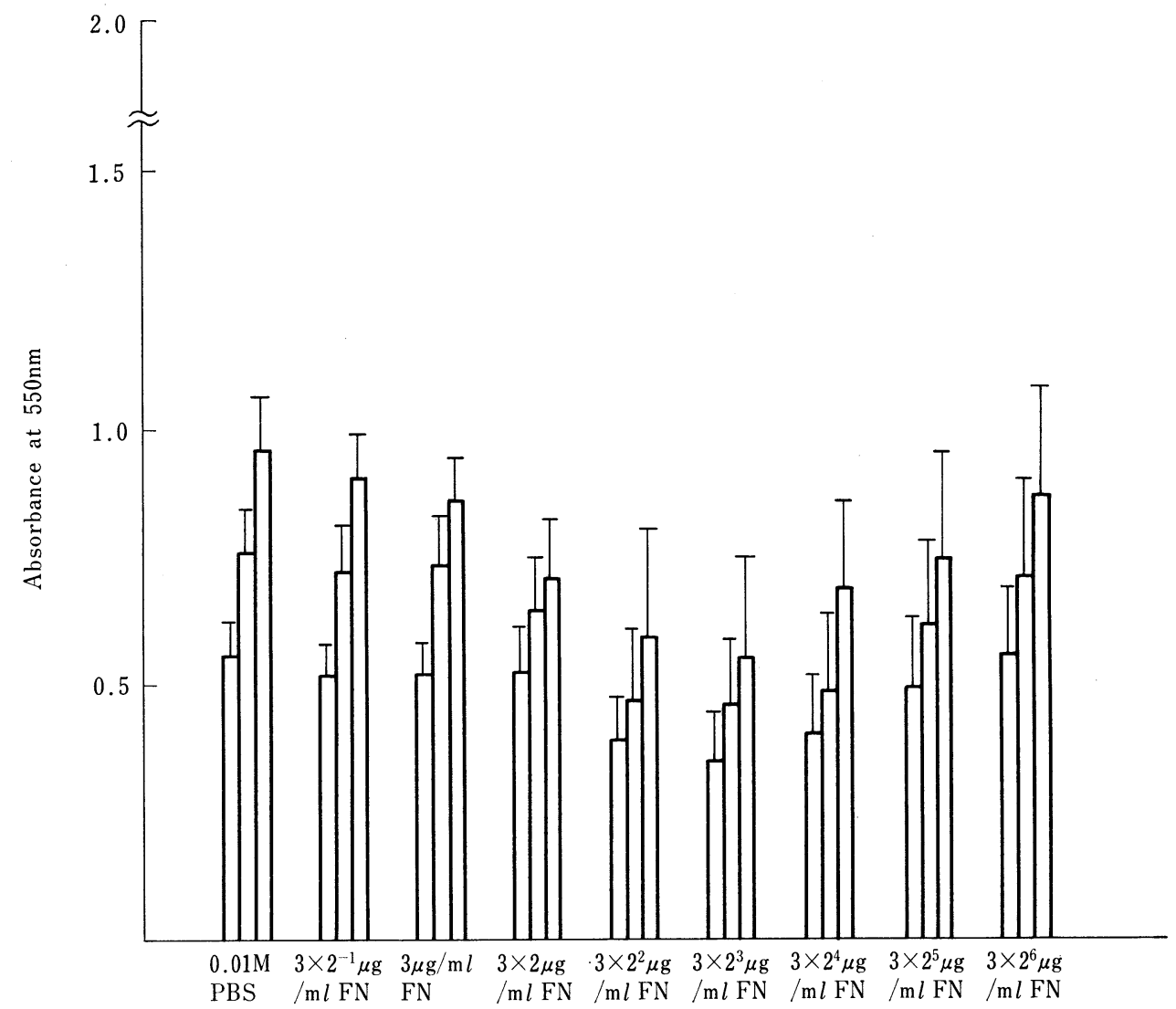

Fig. 1 Comparison of aggregation by FN (aerobic dental plaque)

\section{Hydroxyapatite (HAp) 粉末}

HAp はセントラルガラス社 (宇部研究所) より 供与 されたものを使用した。その比表面積は BET 法により 算出した結果, 平均 $8.4 \mathrm{~m}^{2} / \mathrm{g}$ であった。

\section{4. 歯垢由来細菌の凝集に及ぼす FN の影響}

洞田らの報告に基づき29), FN が HAp に対し最も強い 親和性を有する $192 \mu \mathrm{g} / \mathrm{m} l$ の $\mathrm{FN}$ 濃度から, 精製水での 倍数希釈により $1.5 \mu \mathrm{g} / \mathrm{m} l$ まで 8 段階の $\mathrm{FN}$ 溶液を調 製し, 実験に用いた。各濃度 FN 溶液中に分光光度計を 用いて波長 $550 \mathrm{~nm}$ での OD 值が $1.0,1.5,2.0$ となる ように前述した好気性あるいは嫌気性サンプルを懸濁さ せた。この際, 細菌を含まない各濃度 $\mathrm{FN}$ 溶液の OD 值 は誤差範囲内であった。また FN 不含のコントロールと して 0.01 M PBS 中に好気性及び嫌気性サンプルを同様 に 3 種類の濃度で懸濁して用いた。細菌を懸濁させた各 濃度の $\mathrm{FN}$ 溶液 $10 \mathrm{~m} l$ をシリコン処理した試験管に移し $37^{\circ} \mathrm{C}$ の恒温槽中で 8 時間振盪を行った後, 室温下で 1 時間静置後上層の細菌浮遊液の OD 值を測定することに
より各濃度 FN 溶液中での菌の凝集程度を示すパラメー ターとした。

5. 歯垢由来細菌の HAp への吸着に及ぼす FN の影 響

4 の実験と同様に 8 段階の濃度の $\mathrm{FN}$ 溶液と $0.01 \mathrm{M}$ PBS 中に, 各々の細菌サンプルを 3 種の濃度で懸濁し, 予め $0.01 \mathrm{M}$ PBS で遠沈洗浄を行った HAp を $10 \mathrm{mg}$ ずつ加えピペッティングにより䚓挥した。そして同様に $37^{\circ} \mathrm{C}$ の恒温槽中で 8 時間振盪し, 室温下で 1 時間静 置 後浮遊液の OD 值を測定することにより, 各濃度の FN 存在下での菌の HAp への吸着度を検索した。

\section{実験結果}

\section{1. 㐘垢由来細菌の凝集に及ぼす FN の影響}

本実験では, 細菌を FN 溶液あるいは PBS 中で, 8 時 間加温振盪後, 1 時間静置して得られた上清の OD 值を, 細菌の凝集程度を示すパラメーターとした。従って, 上 


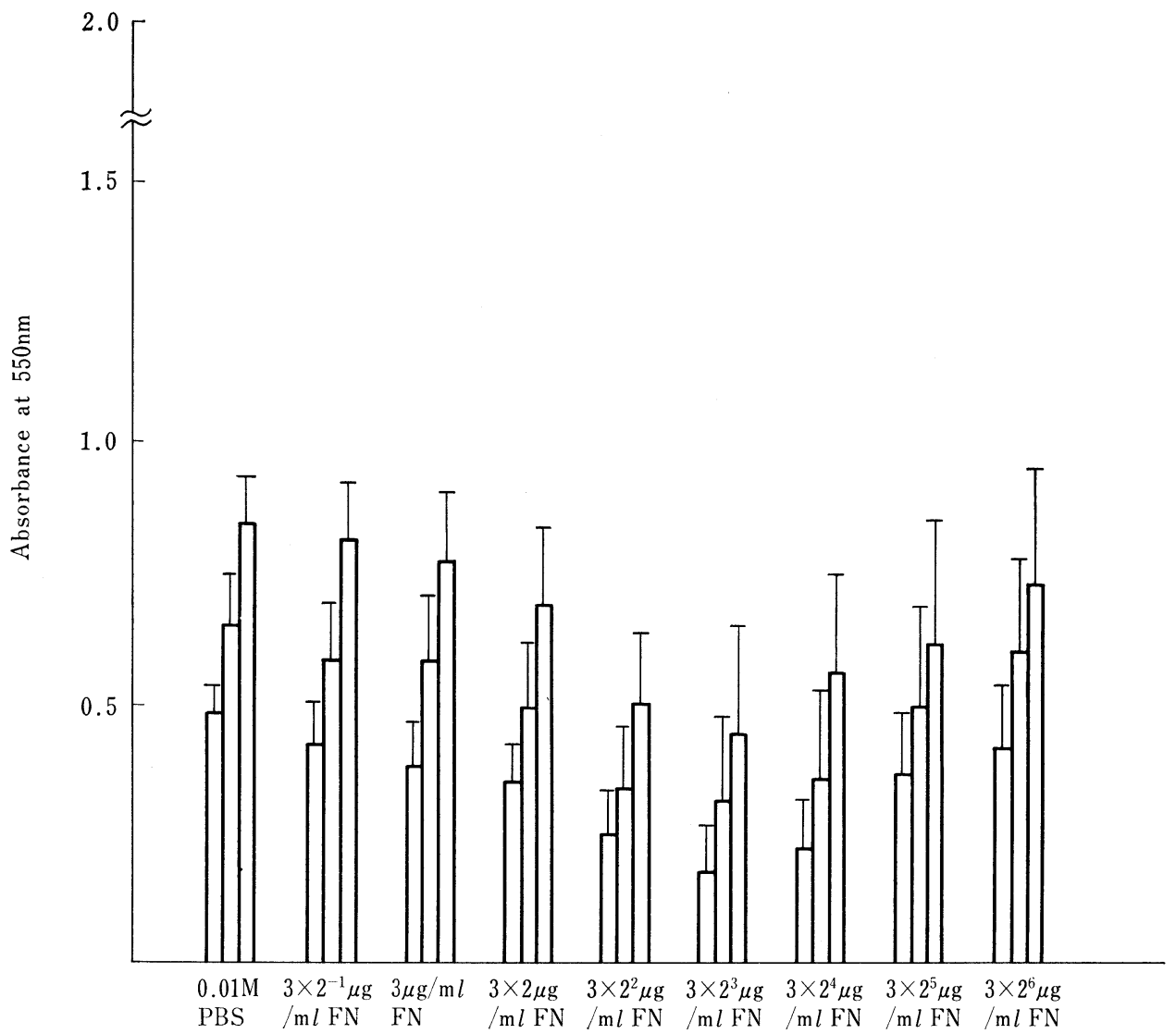

Fig. 2 Comparison of adsorption to HAp by FN (aerobic dental plaque)

清 OD 值の増加は凝集程度が小さいことを示し, 逆に OD 值の減少は凝集程度が大きいことを示す。

a. 好気性サンプル

Fig. 1 に示すように 3 種類の細菌濃度 (OD 值 1.0, 1.5, 2.0) に共通した傾向がみられた。即ち, $\mathrm{FN}$ 濃度が $3 \times 2^{3} \mu \mathrm{g} / \mathrm{m} l$ のときに凝集のピークがみられ，それ以上 あるいはそれ以下の FN 濃度では凝集程度が減少する傾 向にあった。

OD 值 1.0 に懸濁した細菌の凝集程度は, コントロー ルに対して, $3 \times 2^{4} \mu \mathrm{g} / \mathrm{m} l$ の $\mathrm{FN}$ 濃度では $\mathrm{p}<0.05$ の有 意差をもって強 $<, 3 \times 2^{2} \mu \mathrm{g} / \mathrm{m} l$ と $3 \times 2^{3} \mu \mathrm{g} / \mathrm{m} l$ では $\mathrm{p}<$ 0.01 の有意差をもって強かった。OD 值 1.5 に懸濁した 細菌の凝集程度は，コントロールに対して $3 \times 2^{4} \mu \mathrm{g} / \mathrm{m} l$ の $\mathrm{FN}$ 濃度では $\mathrm{p}<0.05$ の有意差をもって強く, $3 \times 2^{2}$ $\mu \mathrm{g} / \mathrm{m} l$ と $3 \times 2^{3} \mu \mathrm{g} / \mathrm{m} l$ では $\mathrm{p}<0.01$ の有意差をもって 強かった。OD 值 2.0 に懸濁した細菌の凝集程 度では $3 \times 2^{2} \mu \mathrm{g} / \mathrm{m} l$ と $3 \times 2^{4} \mu \mathrm{g} / \mathrm{m} l$ の $\mathrm{FN}$ 濃度では $\mathrm{p}<0.05$, $3 \times 2 \mu \mathrm{g} / \mathrm{m} l$ と $3 \times 2^{3} \mu \mathrm{g} / \mathrm{m} l$ では $\mathrm{p}<0.01$ の有意差をも
って強かった。

b. 嫌気性サンプル

Fig. 3 亿示すように OD 值 1.0 および 2.0 の細菌濃度 では $0.3 \times 2^{2} \mu \mathrm{g} / \mathrm{m} l$ の $\mathrm{FN}$ 濃度に凝集のピークがあり, $\mathrm{OD}$ 值 1.5 の細菌濃度では $0.3 \times 2^{3} \mu \mathrm{g} / \mathrm{m} l$ にピークがあ った。それら濃度以下であっても以上であっても, 凝集 の程度は減少する傾向にあった。しかし, OD 值 1.0 に 㲘濁した細菌の凝集程度はコントロールに対して, 全 FN 濃度を通して有意差を認めることは出来なかった。そし て $3 \times 2^{-1} \mu \mathrm{g} / \mathrm{ml}, 3 \mu \mathrm{g} / \mathrm{ml}, 3 \times 2^{5} \mu \mathrm{g} / \mathrm{ml}, 3 \times 2^{6} \mu \mathrm{g} / \mathrm{m} l$ の FN 濃度では凝集の程度はコントロールより, むしろ弱 かった。OD 值 1.5 懸濁した細菌の凝集 程度は, $3 \times 2^{3}$ $\mu \mathrm{g} / \mathrm{m} l$ の $\mathrm{FN}$ 濃度のときにのみ, コントロールに比して $\mathrm{p}<0.05$ の有意な凝集の促進がみられた。そして OD 值 1.0 の場合と同様に, $3 \times 2^{-1} \mu \mathrm{g} / \mathrm{m} l, 3 \mu \mathrm{g} / \mathrm{m} l, 3 \times 2^{5} \mu \mathrm{g} /$ $\mathrm{m} l, 3 \times 2^{6} \mu \mathrm{g} / \mathrm{m} l$ の $\mathrm{FN}$ 濃度では, コントロールより凝 集程度が弱かった。OD 值 2.0 に懸濁した細菌の凝集程 度は $3 \times 2^{2} \mu \mathrm{g} / \mathrm{m} l$ と $3 \times 2^{3} \mu \mathrm{g} / \mathrm{m} l$ では $\mathrm{p}<0.05$ の有意 


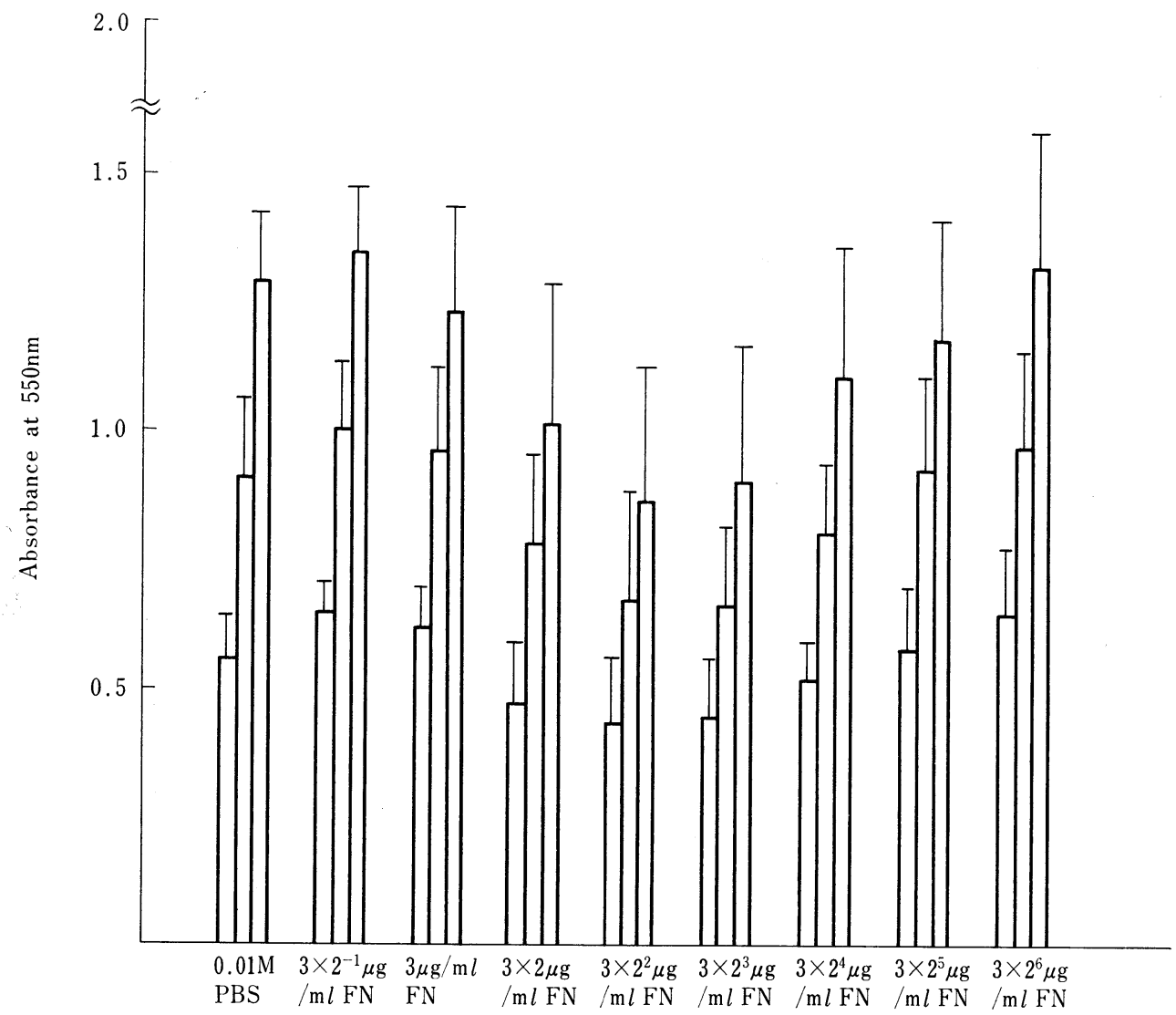

Fig. 3 Comparison of aggregation by FN (anaerobic dental plaque)

差をもってコントロールより凝集程度が強かった。そし て $3 \times 2^{-1} \mu \mathrm{g} / \mathrm{m} l$ と $3 \times 2^{6} \mu \mathrm{g} / \mathrm{m} l$ ではコントロールより 凝集程度が弱かった。

\section{2. 歯垢由来細菌の HAp への吸着に及ぼす FN の影} 響

a. 好気性サンプル

FN 溶液に細菌を懸濁させた系に HAp を加えた場合, その上清の OD 值は, HAp を加えない場合よりも FN 濃 度を通して小さい傾向にあった (Fig. 1，2)。すなわち， HAp に吸着した沈降した細菌量の方が凝集のみによっ て沈降した細菌量より多かった。そのピークは，各細菌 濃度を通して, $3 \times 2^{3} \mu \mathrm{g} / \mathrm{m} l$ の $\mathrm{FN}$ 濃度にあり，それ以 上あるいはそれ以下の FN 濃度では上清の OD 值は大き い傾向にあった（Fig. 2)。

OD 值 1.0 の細菌濃度の場合, コントロールに対して, $3 \mu \mathrm{g} / \mathrm{m} l$ と $3 \times 2 \mu \mathrm{g} / \mathrm{m} l$ の $\mathrm{FN}$ 濃度では $\mathrm{p}<0.05$ の有意 差を認め, $3 \times 2^{2} \mu \mathrm{g} / \mathrm{m} l$ と $3 \times 2^{3} \mu \mathrm{g} / \mathrm{m} l$ では $\mathrm{p}<0.01$ の 有意差が認められた。OD 值 1.5 の細菌濃度の場合には
コントロールに対して $3 \times 2 \mu \mathrm{g} / \mathrm{m} l$ と $3 \times 2^{4} \mu \mathrm{g} / \mathrm{m} l$ では $\mathrm{p}<0.05$ の有意差を認め, $3 \times 2^{2} \mu \mathrm{g} / \mathrm{m} l$ と $3 \times 2^{3} \mu \mathrm{g} / \mathrm{m} l$ 間 では $\mathrm{p}<0.01$ の有意差が認められた。OD值 2.0 の細菌 の場合にはコントロールに対して $3 \times 2^{4} \mu \mathrm{g} / \mathrm{m} l$ では $\mathrm{p}<$ 0.05 で有意差を認め, $3 \times 2^{2} \mu \mathrm{g} / \mathrm{m} l$ と $3 \times 2^{3} \mu \mathrm{g} / \mathrm{m} l$ では $\mathrm{p}<0.01$ の有意差が認められた。

b. 嫌気性サンプル

コントロールに対して, OD 值 1.0 細菌濃度の場合で は $3 \mu \mathrm{g} / \mathrm{m} l$ から $3 \times 2^{4} \mu \mathrm{g} / \mathrm{m} l$ 間では OD 值の減少がみ られ, $3 \times 2^{5} \mu \mathrm{g} / \mathrm{m} l$ では差は認められず, $3 \times 2^{-1} \mu \mathrm{g} / \mathrm{m} l$ と $3 \times 2^{6} \mu \mathrm{g} / \mathrm{m} l$ の $\mathrm{FN}$ 濃度では逆に OD 值が増大する傾 向にあった。OD 值 1.5 および 2.0 に懸濁した細菌も同 様の傾向がみられた。すなわち, $3 \mu \mathrm{g} / \mathrm{m} l$ から $3 \times 2^{5} \mu \mathrm{g} /$ $\mathrm{m} l$ 間では OD 值の減少がみられ, $3 \times 2^{-1} \mu \mathrm{g} / \mathrm{m} l$ と $3 \times 2^{6}$ $\mu \mathrm{g} / \mathrm{m} l$ の $\mathrm{FN}$ 濃度では逆に OD 值が増大寸る傾向にあ った。なお， 3 種類の菌濃度とも FN による HAp への 吸着のピークは $3 \times 2^{2} \mu \mathrm{g} / \mathrm{m} l$ にあった (Fig. 4)。

$\mathrm{OD}$ 值 1.0 の細菌濃度の場合, $3 \times 2^{2} \mu \mathrm{g} / \mathrm{m} l$ と $3 \times 2^{3}$ 


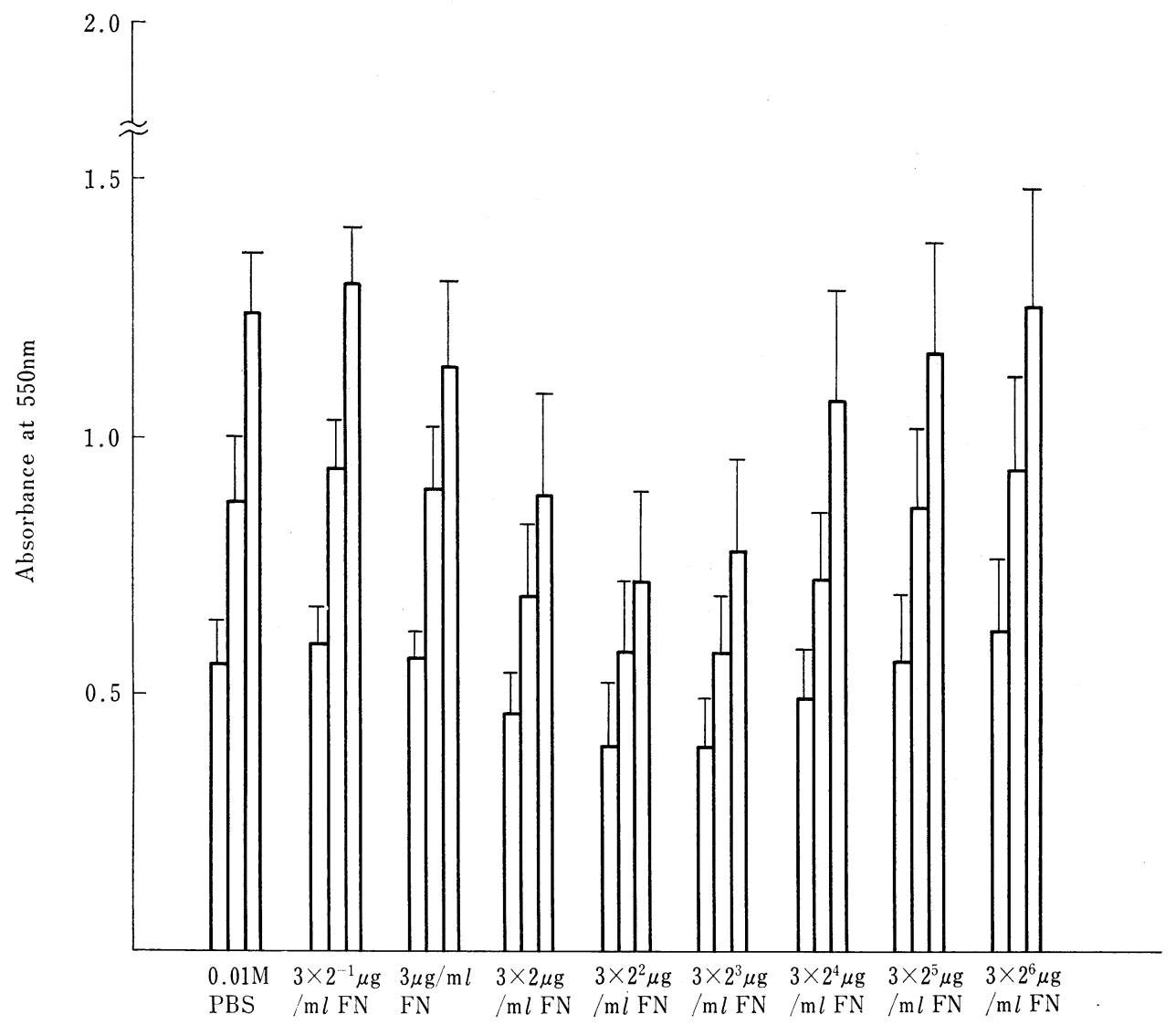

Fig. 4 Comparison of adsorption to HAp by FN (anaerobic dental plaque)

$\mu \mathrm{g} / \mathrm{m} l$ でコントロールに対して $\mathrm{p}<0.05$ の有意差を認 めた。OD 值 1.5 の細菌の場合は $3 \times 2^{2} \mu \mathrm{g} / \mathrm{m} l$ と $3 \times 2^{3}$ $\mu \mathrm{g} / \mathrm{m} l$ では $\mathrm{p}<0.01$ の有意差を認めた。OD 值 2.0 の細 菌濃度の場合は $3 \times 2 \mu \mathrm{g} / \mathrm{m} l$ では $\mathrm{p}<0.05$ の有意差を認 め, $3 \times 2^{2} \mu \mathrm{g} / \mathrm{m} l$ と $3 \times 2^{3} \mu \mathrm{g} / \mathrm{m} l$ では $\mathrm{p}<0.01$ の有意差 を認めた。

\section{考察}

唾液タンパクと歯垢形成との関係は古くから示唆され てきた1,31) が，その中のあるグループは, HApのカルシ ウムやリン酸基との親和性 ${ }^{32)}$ や, 細菌凝集能33) 備えて いることから，刷掃直後の歯面にペリクルとして吸着し た後, 細菌や細菌凝集塊とペリクルとの間の架橋材とし て作用することによって, 歯垢の基質成分になって堆積

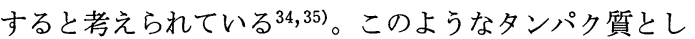
て数種類が報告されているが10 13,36), さらに, ペリク ル, 歯垢, 歯石, 唾液腺細胞に存在し ${ }^{18 ~ 20)}$, 全唾液, 耳
下腺唾液，顎下腺・舌下腺混合唾液中に実際に溶存する $\mathrm{FN}^{23)}$ あるいは $\mathrm{FN}$ 類似物質もこのタンパクグループに

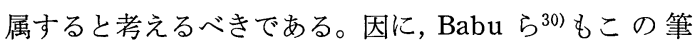
者らの考え方と軌を一にしている。

さて, FN あるいは FN 様物質と歯垢形成との関連性 に関して, 今回, 血漿 FN と歯垢由来細菌および HAp との相互作用について検索を試みた。

1. 㐘垢由来細菌の凝集に及ぼす FN の影響

歯垢を好気的に培養して得られた細菌（好気性サンプ ル）を用いた場合も嫌気的に培養して得られた細菌（嫌 気性サンプル）を用いた場合む，コントロールに比して FN の存在下では明らかに凝集の克進がみられ，諸

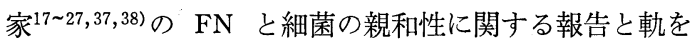
一にする結果を得た。凝集のピークは好気性および嫌気 性サンプルとも, 細菌濃度に関係なく $3 \times 2^{2}$ あるいは $3 \times 2^{3} \mu \mathrm{g} / \mathrm{m} l$ の $\mathrm{FN}$ 濃度にあり，それ以上あるいはそれ 以下の FN 濃度では, 細菌の凝集程度は減少する傾向に あった。今回の実験だけからでは決定的なことは言えな 
いが, FNによる細菌凝集の促進には, FN の最適濃度が 存在する可能性が強く示唆された。すなわち Kuusela $ら^{23,24)}$, Myhre ら ${ }^{25)}$ が報告しているように, もし FN 1 分子中に 2 ケ所あるいはそれ以上の細菌との結合部位が 存在するならば，FN を架橋材とする細菌凝集塊が最も 大きくなり得る FN 濃度が存在すると推測される。

さらに興味深い所見として，嫌気性サンプルにおける 凝集程度は，好気性サンプルの場合より全般的に弱い傾 向があり，とくに嫌気性サンプルでの FN 低濃度域と高 濃度域では PBS コントロールに比べ，凝集程度がむし ろ弱い結果となった。FN には多くの菌種に対する結合 部位が存在すると報告されているが $30,39 \sim 41)$ ，その結合様 式あるいは結合力は菌種によりかなり異なっていると考 えられる ${ }^{42)}$ 。従って, FN による細菌の凝集性は細菌の 種差による結合様式あるいは結合力の違いに強く影響さ れ, 凝集の強い菌種, 凝集の弱い菌種, 凝集が逆に抑制 される菌種が存在すると考えられる。今回我々が用いた 細菌試料は，歯垢を好気的あるいは嫌気的に培養したも のであり，両者とも，かなり多種類に及ぶ菌種が含まれ ていると考えられるが，培養条件の違いにより，両者の 間には構成菌種の違いや，菌数の違いが生じているはず である。従って，今回用いた嫌気性サンプルの系では， 好気性サンプルに比して FNによる凝集の弱い菌種，あ るいは逆に FN により凝集が抑制される菌種が趨勢を占 めていたと推測される。

\section{2. 歯垢由来細菌の HAp への吸着に及ぼす FN の影} 響

細菌の HAp への吸着は FN の存在によって促進され， その程度は FN による細菌の凝集と同様のパターンで各 $\mathrm{FN}$ 濃度ごとに変動した。すなわち, $3 \times 2^{2} \mu \mathrm{g} / \mathrm{m} l$ ある いは $3 \times 2^{3} \mu \mathrm{g} / \mathrm{m} l$ を吸着のピークとして，それ以下ある いはそれ以上の FN 濃度では吸着程度が弱くなる傾向が あった。また，好気性サンプルを用いた系では，嫌気性 サンプルの系より吸着は強くなり, 嫌気性サンプルの系 の $\mathrm{FN}$ 低濃度域および高濃度域では, 細菌の吸着程度は コントロールより弱かった。これらの所見は，凝集実験 の結果と極めて相似性が強い。すなわち, 我々の実験系 では個々の細菌が FNを介して HAp に吸着されるより， 細菌が浮遊状態のときに速やかに凝集が進行し，その結 果生じた凝集塊が HAp に, FN を介して吸着すると考え られ，その結果 FNによる凝集の傾向が吸着実験の結果 によく反映されたのであろう。

この上うな今回の結果㤌，先に報告してきた一連の結

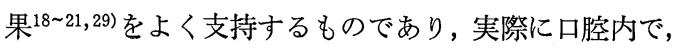

FN が，ペリクルおよび歯垢形成に直接関係している唾 液タンパク質の 1 つとして一役を演じていることが強く 示唆された。

次報にて代表的な口腔内細菌の凝集と HAp への FN による吸着性を検索すると共に，その結合力の強弱，結 合様式を報告する予定である。

\section{結論}

ペリクル及び歯垢形成過程における FN の役割を明ら かにするため，ヒ卜血漿より精製した FN の溶液中に， 歯垢を好気的及び嫌気的に培養して得た細菌を懸濁さ せ，FN の凝集に与える影響を調べた。さらに同様の系 に HAp を混じて, 菌の HAp への吸着に与える FN の 影響を調べた。その結果以下の結論を得た。

1. ヒト血漿 FNにより, 歯垢由来細菌の凝集が促進 された。

2. ヒト血漿 FNにより, 歯垢由来細菌の HAp への 吸着が促進された。

3. ヒト血漿 FNによる細菌の凝集及び吸着には, 最 適 FN 濃度があり，それ以上であってもそれ以下であっ ても反応は弱くなる。

4. 口腔内に扔いて, FN あるいは FN 類似タンパク が，一部の唾液タンパクと同様, ペリクル，歯垢形成に 直接関与している可能性が強く示唆された。

\section{謝 辞}

本研究費用の一部として宮田奖励金を利用させていただきま した事に謝辞を表します。

\section{文献}

1) Gibbons, R.J. and Houte, J.V. : Bacterial adherence in oral microbial ecology. Microbiol., 29 : 19-44, 1975.

2) Rölla, G. : Inhibition of adsorption-general considerations. Microbial Aspects of Dental Caries, $2:$ 309-324, 1976.

3) Olsson, J., Glantz, P.O. and Krasse, B. : Surface potential and adherence of oral streptococci to solid surfaces. Scand. J. Dent. Res., 84 : 240242,1976

4) Olsson, J. and Glantz, P.O. : Effect of $\mathrm{pH}$ and counter ions on the zeta-potential of oral strep- 
tococci. Arch. oral Biol., 22 : 461-466, 1977.

5) Reynold, E.C. and Wong, A. : Effect of adsorbed protein on hydroxyapatite zete potential and streptococcus mutans adherence. Infect. Immun., 39 : 1285-1290, 1983.

6) Abbott, A. and Hayes, M.L. : The conditioning role of saliva in streptococcal attachment to hydroxyapatite surfaces. J. Gen. Microbiol., $130: 809-816,1984$.

7) Gibbons, R.J. and Qureshi, J.V. : Inhibition of adsorption of streptococcus matans strains to saliva-treated hydroxyapatite by galactose and certain amines. Infect. Immun., 26 : 1214-1217, 1979.

8) Gibbons, R.J., Moreno, E.C. and Etherden, I. : Concentration-dependent multiple binding sites on saliva-treated hydroxyapatite for streptococcus sanguis. Infect. Immun., $39: 280-289$, 1983.

9) Liljemark, W.F. and Schaver, S.V. : Competitive bing among oral streptococci to hydroxyapatite. J. Dent. Res., 56 : 157-165, 1977.

10) Hay, D.I. : The interaction of human parotid salivary proteins with hydroxyapatite. Arch. oral Biol., 18 : 1517-1529, 1973.

11) Hay, D.I. and Oppenheim, F.G. : The isolation from human parotid saliva of a further group of proline-rich-proteins. Arch. oral Bilol., 9 : 627-632, 1974.

12) Hay, D.I. : Fractination of human parotid salivary proteins and the isolation of an histidinerich acdic peptide which shows high affinity for hydroxyapatite surfaces. Arch. oral Biol., $20: 553-558,1975$.

13) Kousvelari, E.E., Baratz, R.S., Burke, B. and Oppenheim, F.G. : Immunochemical indentification and determination of proline-rich proteins in salivary secretions, enamel pellicle and glandular tissue specimens. J. Dent. Res., 59 : 1430-1438, 1980.

14） 久保木芳徳 : 唾液タンパク質と歯質との反応につ いてーAcquired pellicleをめぐる Hay, Gibbons および Belcourt らの仕事の批判一，虫歯のシン ポジウム，歯苔とエナメル質のかかわり合い， 口
腔保健協会, 東京, 1977, 23.

15）久保木芳徳 : 唾液の生化学的性質と 齟 蝕 $-\mathrm{Ca}^{++}$ 反応性タンパク質を中心にして一. 歯界展望, 齲 蝕を考える，112-117，1982.

16) Yamada, K.M. and Olden, K. : Fibronectinsadhesive glycoproteins of cell surface and blood. Nature, 275 : 179-184, 1978.

17) Abraham, S.N., Beachey, E.H. and Simpson, W.A. : Adherence of streptococcus pyogenes, escherichia coli, and psedomonas aeruginosa to fibronectin-coated and uncoated epithelial cells. Infect. Immun., 41 : 1261-1268, 1983.

18）竹内 宏, 堀 泰典, 干 世鳳, 金久純, 阿倍 公生, 佐藤 勝, 兼松宣武, 藤井輝久 : Fibronectin による歯垢, 歯石の形成機序, 第 1 報, 唾液 腺, 分泌唾液における fibronectin の証明. 日歯 周誌, $26: 83-87,1984$.

19）竹内 宏, 干 世鳳, 堀 泰典, 金久純也, 藤井 輝久, 佐藤 勝, 並河 勇, 巽 幹雄, 高木順彦: Fibronectin による歯垢，歯石の形成機序，第 2 報, 獲得被膜における fibronectin の証明. 日歯 周誌, $26: 257-261,1984$.

20）田島一範，干世鳳，玉木直子，上田裕康，堀 泰典，金人純也，竹内 宏，村上純一, 河内準治, 岩山幸雄 : Fibronectin による歯垢, 歯石の形成 機序，第 4 報，歯石における Fibronectin の局 在. 日歯周誌, $26: 701-709,1984$.

21）玉木直子, 干世鳳, 上田裕康, 田島一範, 堀 泰典, 金久純也, 竹内 宏, 佐藤 勝, 藤井輝久 : Fibronectin による歯垢, 歯石の形成機序, 第 3 報, ヒト唾液中における溶存 fibronectin の定量. 日歯周誌, $26: 696-700,1984$.

22) Pierschbacher, M.D. and Ruoslaht, E. : Cell attachment activity of fibronectin can be duplicated by small synthetic fragments of the molecule. Nature, $309:$ 30-33, 1984.

23) Kuusela, P., Vartio, T., Vuento, M. and Myhre, E.B. : Binding sites for streptococci and staphylococci in fibronectin. Infect. Immun., 45 : 433-436, 1884.

24) Kuusela, P., Vartio, T., Vuento, M. and Myhre, E.B. : Attachment of sttaphylococci and streptococci on fibronectin, fibronectin fragments, and fibrinogen bound to a solid phase. Infect. 
Immun., $50: 77-81,1985$.

25) Myhre, E.B. and Kuusela, P. : Binding of human fibronectin to group A.C. and G streptococci. Infect. Immun., $40: 29-34,1983$.

26) Tamaki, T. and Aoki, N. : Cross-linking of $\alpha_{2}$ plasmin inhibitor and fibronectin to fibrin by fibrin-stabilizing factor. Biochim. Biophys. Acta., $661: 280-286,1981$.

27) Simpson, W.A. and Beachey, E.H. : Adherence of group A streptococci to fibronectin on oral epithelial cells. Infect. Immun., $39: 275-279$, 1983.

28) Pommier, C.G., Oshea, J., Chused, T., Yancey, K., Frank, M.M., Takahashi, T. and Brown, E.J. : Studies on the fibronectin receptors of human peripheral blood leukocytes. J. Exp. Med., 159 : 137-151, 1984.

29）洞田直子, 田島一範, 竹内 宏, 土井 豊, 森脇 豊, 藤井輝久, 龁谷耕司, 紀藤信哉, 阿部龍二 : Fibronectin による歯垢, 歯石の形成機序, 第 5 報, リン酸溶液中での fibronectin の hydroxyapatite への吸着実験. 日歯周誌, $28: 125-130$, 1986.

30) Babu, J.P., Simpson, W.A., Courtney, H.S. and Beachey, E.H. : Interaction of human plasma fibronectin with cariogenic and noncariogenic oral streptococci. Infect. Immun., 41 : 162-168, 1983.

31) Leach, S.A. : Release and breakdown of sialic acid from human salivary mucin and its role in the in the formation of dental plaque. Nature, 199 : 486-487, 1963.

32) Bernandi, G., Giro, M.G. and Gaillard, C. : Chromatography of polypeptides and proteins on hydroxyapatite columns: some new developments. Biochim. Biophys. Acta., 278 : 409420, 1972.

33) Hay, D.I., Gibbons, R.J. and Spinell, D.M. :
Characteristics of some high molecular weight constituments with bacterial aggregating activity from whole sliva and dental plaque. Caries Res., 5 : 111-123, 1971.

34) van Houte, J. : Bacterial adhesion in the mouth, In S.A. Leach (ed.), Dental plaque and surface interactions in the oral cavity, 1979, 69-100.

35) Lie, T. : Ultrastructual study of early dental plaque formation. J. Periodontal Res., 13 : 391409, 1978 .

36) Gibbons, R.J. and van Houte, J. : Bacterial adherence in oral microbial ecology. Ann. Rev. Microbiol., 29 : 19-44, 1975.

37) Toy, P.T.C.Y., Lai, L., Drake, T.A. and Sande, M.A. : Effect of fibronectin on adherence of staphylococcus aureus to fibrin thrombi in vitro. Infect. Immun., 48 : 83-86, 1985.

38) Sorvillo, J.M. and Pearlstein, E. : Clq, a subunit of the first component of complement, enhances binding of plasma fibronectin to bacteria. Infect. Immun., 49 : 664-669, 1985.

39) Doran, J.E. : A critical assessment of fibronectin's opsonic role for bacteria and microaggreates. vox Sang, $45: 337-348,1983$.

40) Mosesson, M.W. and Amrani, D.L. : The structure and biologic activities of plasma fibronectin. Blood, 56 : 145-158, 1980.

41) Water, L.V.D., Destree, A.T. and Hynes, R.O. : Fibronectin binds to some bacteria but does not promote their uptake by phagocytic cells. Science, 220 : 201-204, 1983.

42) Stanislawski, L., Simpson, W.A., Hasty, D., Sharon, N., Beachey, E.H. and Ofek, I. : Role of fibronectin in attachment of streptococcus pyogenes and escherichia coli to human cell lines and isolated oral epithelial cells. Infect. Immun., 48 : 257-259, 1985. 